\title{
Glutathione S-Transferase Theta-2
}

National Cancer Institute

\section{Source}

National Cancer Institute. Glutathione S-Transferase Theta-2. NCI Thesaurus. Code C158390.

Glutathione S-transferase theta-2 (244 aa, $28 \mathrm{kDa}$ ) is encoded by the human GSTT2 gene. This protein is involved in the conjug ation of glutathione to hydrophobic electrophiles. 